\title{
Governance and Board Member Identity in an Emerging Nonprofit Organization
}

\author{
Jeffrey J. Aulgur, Ed.D. \\ Arkansas Tech University, Russellville, AR
}

\begin{abstract}
Organizational effectiveness is a term without a single definition about the nonprofit community; it is difficult to define, much less measure, due to the wide disparity in that community. Inconsistency in the sector leads to an array of hypotheses in the literature addressing organizational effectiveness. Through a comprehensive examination of a single nonprofit organization, this qualitative case study examines the gap between the expectations of board performance by the nonprofit organization's senior leadership and the board members' selfperception of their governance role. The dominant self-perception of the board of directors is that their value as a governing entity is in their willingness to work hands-on in whatever volunteer roles are necessary to sustain the organization. Organizational governance is secondary to this self-characterization as a working board. This lack of focus on formal governance has resulted in a governing structure with minimal development, even as the organization itself continues to enjoy success. The case study of a single nonprofit entity suggests some recommendations for the practice of nonprofit governance in general as well as future research in the domain of nonprofit organizations that are either embryonic or have limited means available for the professional development of the board.
\end{abstract}

Keywords: nonprofit governance, board member perception, strategic planning, advisory board

ndividuals serving as nonprofit board members are the organization's ambassadors, advocates, and community representatives who function as stewards of the public trust by exercising a legal and fiduciary responsibility (Kendall, 2009; Wolf, 1999). Nonprofit directors in the United States are, with few exceptions, unpaid volunteers. Green and Griesinger (1996) found most nonprofit organizations lacked commitment to board member training and development. The lack of time available for volunteers, combined with little board member development, contribute to a sector administered by individuals who have minimal relevant knowledge.

Organizational effectiveness is a term without a single definition in relation to the nonprofit community; it is difficult to define, much less measure, due to the wide disparity in that community. Inconsistency in the sector leads to an array of hypotheses in the literature addressing organizational effectiveness. Callen, Klein, and Tinkelman (2003) argued that no single criterion of organizational effectiveness is 
viewed equally in the nonprofit community. Others indicate an explicit mechanism behind a wellperforming board and an efficient organization does not exist (Mwenja \& Lewis, 2009). Mwenja and Lewis (2009) stated that organizational performance is ultimately a social construct-one that, combined with poorly articulated goals, makes the development of a single model of measurement of nonprofit effectiveness virtually impossible.

Nonprofit organizational effectiveness, suggested Herman and Renz (2008), is multidimensional and a matter of comparison. They offered nine traits to consider when examining nonprofit effectiveness: always comparative; multidimensional; related to board effectiveness (although how is not clear) and to the use of correct management practices; a social construction; universal "best practices" are unlikely to exist; organizational responsiveness is an effective organizational-level measure; distinctions among nonprofits must be made; and the depth and breadth of the analysis must be considered. Herman and Renz (2000) also claimed that nonprofit organizational effectiveness was directly related to the efficacy of the board of directors. However, O'Regan and Oster (2005) maintained the difficulty of empirically measuring the relationship between organizational success and the effectiveness of the governing board.

There is no definitive answer as to what constitutes an embryonic nonprofit organization in the normative or academic literature, although it may be defined by certain measurable milestones, such as achieving charitable status as recognized by the Internal Revenue Service, the publication of an annual report, or receiving an external financial audit. However, none of these milestones speak to the growth and development of an organization's board of directors and the ability of that board to effectively govern. While deeming an organization embryonic is a subjective interpretation, I labeled my case study research subject in this way based on the literature, combined with my own experience as a nonprofit practitioner and professional over a 20 year period.

Through a comprehensive examination of a single nonprofit organization, this qualitative case study examines the gap between the expectations of board performance by the nonprofit organization's senior leadership and the board members' self-perception of their governance role. My anecdotal experience indicated most nonprofit governing boards operate more from their historical basis than from any governance standard defined in the normative or academic literature. Additionally, small or embryonic nonprofit organizations do not have the financial resources to invest in training, development, and strategic planning as do larger and more established organizations. An identified need exists in the field of nonprofit governance research to examine multiple levels and units of analysis, and the emerging nonprofit is an underresearched domain (Renz \& Andersson, 2014). My perspective is that no one board of directors governs its nonprofit organization in a pre-defined manner. A single theory or hypothesis capable of addressing the challenges of nonprofit governance is nonexistent. Each nonprofit must evaluate the available options and select a path based on its collection of personalities, culture, and external pressures (Brudney \& Murray, 1998; Ostrower \& Stone, 2009). Regardless of the theory, model, or framework of governance, the organization must identify governance challenges requiring the interaction of the board of directors and the chief executive officer (Kreutzer, 2009). 
Board development "entails the range of activities related to building and maintaining an active board of directors" (Brown, 2007, p. 303). Carver (2006) identified that the responsibility for board development rests with the board of directors itself; other responsibilities noted by Carver included job design, discipline and performance evaluation. Although board of director development and training is standard in the nonprofit community, little evidence exists to support any empirical impact on board performance (Holland \& Jackson, 1998). It is rare that a board of directors sets clear expectations and standards for its membership and applies those expectations to its own dynamic (Holland, 2002). Most boards, according to Holland, are satisfied to neglect the same standards for themselves that they established for the executive or leadership team.

Historically, it has been the norm for board of director training and development to consist of a meeting with the executive director, a review of documents associated with mission and history (e.g., bylaws and minutes), and a tour of the physical plant (Green \& Griesinger, 1996). Board development needs to be long-term and not consist only of a retreat or general development during board meetings (Holland \& Jackson, 1998). To be a high-performing board, argued Jansen, Kilpatrick, and Cvsa (2006), the membership must be willing to examine its performance on a regular, if not continual, basis, while identifying improvement opportunities and making the changes needed for organizational betterment. It is the responsibility of the board of directors itself to manage its development, discipline, and job performance, and these goals should be formulated by individual diagnostic assessments and action plans (Carver, 2006; Holland \& Jackson, 1998). Initial and recurring board training potentially enhances board performance and effectiveness (Abben, 2011; Brown, 2007; Green \& Griesinger, 1997). In a study of nonprofit organizations with revenues of more than \$1 million, Brown, Hillman, and Okun (2011) found that continued board member training predicted board member participation in both resource development and organizational monitoring roles. Barriers to improving overall performance identified by Holland (1998) include a lack of clear expectations, failure to understand the need for change, previous change failures, and difficulty in putting aside past practices in favor of new initiatives. Organizations, as well as individual board member candidates, should examine the potential motivation for service on a particular nonprofit governing board (Inglis \& Cleave, 2006).

Nonprofit organizations vary considerably in size, scope, and complexity. Board members are often selected based on the perceived stature of the organization and not necessarily for identified skills or nonprofit experience. The majority of nonprofit organizations have no direct governance guidance other than the paradigm established by the organizations' boards of directors. Given the lack of external agreement, nonprofit organizations are left to decide what constitutes effective board development and governance, with each nonprofit evaluating options and selecting a path based on its collection of personalities, culture, and external pressures (Brudney \& Murray, 1998). Judy Freiwirth (2012) summarized the governance challenge: "It has become increasingly clear within the nonprofit sector that traditional governance models are often inadequate in effectively responding to the rapidly changing environment and other challenges faced by many nonprofits and their communities" (p. 183). 


\section{Method}

The purpose of this case study was to explore the self-perception of the governance role by the board of directors. The single case study research of TSI Rehabilitation offers an opportunity to gain, as described by Flyvbjerg (2006), a nuanced view of the reality of the governance of a fledgling nonprofit organization. Case study research of a nonprofit organization allows "for immersion in the meeting environment and deep exploration of the experiences, roles, and motivations of individual members" (Beck, 2014, p. 103). Conducting individual semi-structured interviews with the participating board of directors, the executive director, and primary benefactor(s) of the organization provides an opportunity to gain a level of intimacy and depth not available through a quantitative approach. My goal is to utilize the knowledge attained through this research effort to assist in the development of a process-based analysis model to aid emerging nonprofit organizations in their governance efforts.

\section{Context of the Study}

Observation of behavior in everyday situations provides a depth of knowledge not readily available in quantitative research, especially in social settings or activities viewed from the perspective of the participants (Bloomberg \& Volpe, 2008; Rossman \& Rallis, 2003; Silverman, 2000). While qualitative research has its roots, at least in part, in empiricism, qualitative researchers strive to give a voice to the subject (Rossman \& Rallis, 2003). According to Maykut and Morehouse (1994), the qualitative researcher must engage in what they termed "indwelling," which requires an empathetic relationship with study participants.

As described by Creswell (2007), qualitative research will "let the voices of our participants speak and carry the story through dialogue" (p. 43). The voices of members only speak when examined through context. The reality is socially constructed; hence, individuals develop subjective meaning about their personal experiences that may only be understood through immersion in the reality of the participants in the world where they live and work (Bloomberg \& Volpe, 2008; Creswell, 2007; Maxwell, 1998). A qualitative approach is necessary to discover the perceptions of nonprofit board members within the context of their organizational governance paradigm.

The subject of the study is a nonprofit entity providing therapeutic riding and hippotherapy to individuals with disabilities. Hippotherapy is a physical, occupational, and speech therapy treatment that utilizes equine movement. The assets of this organization are limited for an operating nonprofit organization; from 2010 to 2011 , net assets decreased from $\$ 18,048$ to $\$ 5,582$ due to an operating loss of $\$ 12,466$ in FY 2011. Revenue decreased by $27 \%$ in FY 2011, primarily due to a decrease in fundraising of more than $\$ 11,000$. This was coupled with a $24 \%$ increase in expenses, primarily in contracted labor for the provision of direct therapy services to program recipients. TSI Rehabilitation (pseudonym) relies upon Medicaid fee-for-service revenue. 


\section{Procedures}

Interviewing nonprofit board members is one part of the qualitative data collection process. I anticipated direct observation of board meetings of the subject nonprofit might yield a dynamic different from that offered in the interviews or clarify the relationship between the board and the chief executive officer. Next, the chief executive of the organization was interviewed separately from the members of the board. To analyze the role of nonprofit board members solely from the perspective of board members would present only a single side of the relationship. Not all board members participated in the interview process, but the majority provided both initial and follow-up interviews.

The data pool drew upon multiple resources, including observation of board meetings, review of organizational documents (by-laws, articles of incorporation, board meeting minutes, and Internal Revenue Service Form 990), web presence, and publicity publications. I triangulated data from multiple sources to confirm the validity of potential outcomes (Tellis, 1997). Glaser and Strauss (1967) used the term "slices of data" to identify the results of the use of multiple sources of data and the variety of data and views produced from varying vantage points.

\section{Data Analysis}

The fieldwork generated significant raw data that was coded and evaluated to uncover any dominant themes. After data reduction and codification, the qualitative data yielded patterns reviewed through triangulation of the sources. Emergent patterns developed into potential explanations of the perceived roles of nonprofit board members. During the coding process, I remained aware of my personal bias and was willing to question all findings due to my previous experience in nonprofit corporations. However, my experience as a practitioner in the nonprofit community was a considerable asset to data collection and analysis.

At the completion of the coding process and reviewing the data collected from supporting documents and observations, I developed a tentative set of categories. The names allocated to each group were influenced by my anecdotal knowledge of the nonprofit sector as a professional and practitioner, as well as my review of the academic and normative literature. Merriam (2009) noted the names of categories are typically derived from the researcher, the participants, and subject resources, but they are most often what the researcher sees in the data. Merriam (2009) also stated that the themes derived from a research effort must not only be responsive to the research question or questions but also as sensitive to the data as possible; exhaustive enough to encompass all relevant data; mutually exclusive (a relevant unit of data placed in only one category); and conceptually congruent (all categories are at the same conceptual level).

\section{Findings}

At the conclusion of my category development process and a review of the data, I constructed six major themes. The themes were (a) a lack of consensus of the meaning of nonprofit governance, (b) establishing credibility and pursuing sustainability-driven decision making, (c) the influence of a non- 
governing advisory board, (d) organizational reliance upon a single benefactor, (e) evidence of resource dependency governance, and ( $f$ ) absence of strategic planning.

Board members' perception of governance. During the data collection process, it became apparent that there was no clear consensus among board members as to the meaning of nonprofit management within TSI Rehabilitation's framework. The executive director indicated board members did not primarily constitute TSI Rehabilitation's decision-making forum: "Some of the things we do at our meetings are informative. Less about making decisions and more about informative-l'm giving you information." She further noted ambiguity with the meaning of nonprofit governance: "And what does governance mean? And what would you define as governance? Because, obviously, in my mind, governance may mean something different than what another board member may think."

The role of the board in governance is a theme that continued to emerge throughout the process. Board members struggled with the idea of moving away from a working board of directors, a board directly and heavily involved in all activities of the organization, to a governing board.

I think later, down the road, just me, I would say much later down the road . . I I can see that transitioning over, I can see some of the working board still being there and bringing on other people to do the work and the board to govern, since they've been there and experience speaks volumes with me. (Sloan)

It probably eventually should, is what I'm thinking. You know, where you have enough people underneath that can do all of this stuff that we're doing. To me, it makes sense to me that that would by the natural progression. But, I imagine that if it's the same board members, they probably like to get their hands dirty if they can. (Doug)

A statement provided by a founding board member five years after TSI Rehabilitation's establishment as a nonprofit corporation articulated the organizational mindset: "We are still getting off the ground. Even as successful as we are, we really are."

Establishing credibility and pursuing stability. Credibility, combined with stability, are critical components to the survivability of an embryonic nonprofit organization. In the case of TSI Rehabilitation, financial resources were limited, and relatively substantial financial expenditures had to be carefully weighed. The board determined it necessary to invest in a financial audit for two reasons: to establish external credibility and to become eligible to apply for local United Way funding.

I was about to use the word "credibility." We might be the smallest organization that ever applies for some of these grants but because of the protocol, we have the same credibility as the American Cancer Society. We've done all the same things for that level of grant application, and so, but we don't have the money. (Robert)

One board member offered a different perspective regarding the audit from a cost versus benefits viewpoint: "And there was a discussion about it, because it came down to do we pay for feed or do we 
invest in this?" Another member of the board viewed organizational credibility from an entirely different angle: "Our inefficiency comes from the fact that we don't have a celebrity status member or a celebrity status promoter."

In both the for-profit and the nonprofit sectors, sustainability is a factor for long-term growth. A component of achieving stability is articulating the needs of the organization. The executive director identified capital expenditures with need: "And l'd like to have more office space and l'd like to have a horse shelter, and it's all about growth. That's how I see it." One board member articulated funding as the key need of TSI Rehabilitation: "If we could get some regular cash flow coming in that would sustain it, it would be the main goal right now."

A statement by the board president indicated the level of the disconnect between the staff and the governing body regarding expenditures:

When I asked . . . at one point, what's it cost for a year's worth of therapy for a child, she came up with a number of like $\$ 250$, which was the first scholarship amount. Once they did that [examined actual expenses], they found that the cost was closer to $\$ 1,000$, for a year.

Sustainability will remain a critical challenge for the organization if its leadership cannot articulate the financial cost of meeting the mission. The executive director summarized the organization's operating financial position: "But we need to figure out how to make it next month." Erin expressed her frustration with the economic instability: "We're almost like the local animal shelter on that trying to raise money here. It's just the financial end is very difficult." Finally, a board member made a connection between economic instability and a lack of financial planning: "I mean, it's almost like we haven't found that magic formula to make everything run smoothly. Like you said to tune up the car so it runs. So, I think that fits what we need to do. It's just finding that magic formula."

Strategic planning. TSI Rehabilitation will remain operationally challenged without consistent and reliable sources of funding for mission delivery. Funding is one area the organization could address with a strategic planning process, but strategic planning is nonexistent within the organization. When I asked the president of the board of directors if TSI Rehabilitation engaged in strategic planning, he replied, "As a board? No." William added the organization continued to operate without a business plan in place: "We don't have a formal business plan yet. It will probably take me having the time to sit down and just start writing it, which I don't mind." Members of the TSI Rehabilitation board of directors consistently expressed the need for organizational strategic planning for future sustainability and growth but admitted day-to-day operational survival was the priority:

So, no matter what organization you are and how big you are, or anything else, if you don't continue to grow and change and adapt, then you are going to have a problem. (Erin)

Not really. We-I think I might remember one kind of strategic planning meeting that sort of addressed that issue, but when you are faced with again, how are we going to pay the light bill? (Tyler) 
My thing is maybe to help us work more efficiently to the point where we can set the long-term goals and it's not so the firefighting. . . It's been suggested that we have a strategic planning session, but it just hasn't happened yet. (Doug)

The board of directors does not have the background or experience in nonprofit governance to make the critical connection between strategic planning and long-term sustainability. The key concern expressed is short-term survivability, with little thought having been given to long-term sustainability.

The presence and influence of a non-governing advisory board. The executive director and board members referenced an advisory council during the interview process. If the second group of individuals guided TSI Rehabilitation, I wanted to know who they were and what role, if any, they played in the governance domain. The relationship between TSI Rehabilitation, the advisory board, and the executive director is complicated. In addition to the benefactor relationship with TSI Rehabilitation, Susan is the primary employer of the executive director outside of her role as executive director. Susan owns and operates a therapy clinic where the executive director is employed. TSI Rehabilitation contracted with Susan's therapy clinic to provide the hippotherapy delivered at the arena and to invoice the state Medicaid program for reimbursement.

Because of the unique relationship of the benefactor couple with TSI Rehabilitation, my initial questions to the executive director focused on any conflicts of interest, real or perceived. The benefactor addressed her advisory role: "I just can't be a board member because I'm a property owner. So, advisor counsel kind of lets me-we bounce ideas off each other." She was very aware of the danger of a conflict of interest perception regarding her therapy business and its role with TSI Rehabilitation. She quickly clarified that her relationship with TSI Rehabilitation, although proprietary as a provider of therapy services, was not financially beneficial to her therapy clinic: "We're not making any money off of it. It's actually costing us money, but so, it's not the financial gain, its the mission." The benefactor discussed at length her desire to ensure there was a clear distinction between her two roles, purposely maintaining a distanced relationship with the board of directors: "Well, this is part of, maybe the area I need to grow in, but I really need to stay out of the picture because of the revenue I receive. I really don't know all of the board members."

Through her speech and body language during the interviews, the benefactor's deep passion about hippotherapy and its benefits to individuals with developmental disabilities were very apparent. Given the explicit financial commitment of her and her husband, I asked how she might feel if TSI Rehabilitation outgrew their adjacent property. The benefactor replied, "I would be ok if they outgrew our place and had to relocate. I would be ok with that. They were outgrowing our little 10 acres, so we went ahead and invested in the land behind us." She explained she and her husband purchased the additional ten acres adjacent to their own at a price above market value solely for the benefit of TSI Rehabilitation.

TSI Rehabilitation, as a nonprofit organization, relies heavily on the generosity of these husband and wife benefactors and their role as an advisory body. This reliance upon a single donor for the delivery of day-to-day operations raised not only questions about sustainability, but also survivability. I asked each 
board member if this reliance presented any degree of risk to TSI Rehabilitation. Board members expressed concern about their lack of knowledge of any legal agreements between the benefactors and the organization regarding the use of the land and equipment and it was apparent that they perceived a risk: "Without really knowing the legal structure that's been set up - yeah, I think it's risky. If there's ever a falling out, I mean-I confess, I don't really know that the legal structure is."

I asked William, the board president, if he believed this reliance upon a single donor was in some way restricting the growth and development of the organization. He responded: "I believe that if they took more of the micromanagement aspect to it or if we had to continually go back and get more money from them, then, yes, it would hold us back. ... So, I don't believe that they are holding us back. I don't think that they have limited us. I think that we are limited by our own resources. We're not limited that badly."

To bring the concept full circle, I asked the benefactor if she believed the generosity of her and her husband enabled the leadership of TSI Rehabilitation and indirectly restricted organizational growth. She replied, "Yeah, I've never looked at it from that relationship concept - enabling them to be dependent. You know, because I'm sitting back hoping they grow. I want them to grow. I'd love them to stay here, but if they don't, we're going to have a really nice barn." The benefactor acknowledged the organization was not yet financially stable or independent, and its long-term future and sustainability were not yet assured.

\section{Discussion}

The findings indicate there is no consensus about the meaning of nonprofit governance among the board of directors of TSI Rehabilitation; this directly relates to the board members' perception of their role in governance and operations. There is limited research on the key roles expected of nonprofit board members; these limited findings suggest a broad range of functions and responsibilities among board members and their organizations' management (Liu, 2010; Stone \& Ostrower, 2007). A board member's perception of effectiveness correlates with role ambiguity, which is measured by how well a board member understands what he or she is supposed to do, as well as the relationship of these actions to organizational goals (Doherty \& Hoye, 2011). However, it is not unusual for board members to experience role ambiguity within the same organization (Liu, 2010).

The emergent theme from the findings is the self-characterization of the board as a "working board," as opposed to a "governing board," which was focused on actions ensuring short-term fiscal viability and providing the support required to continue operations. The role adopted is not that different from what O'Regan and Oster (2005) described as the three W's of nonprofit board members: "wealth (donations and fundraising), wisdom (monitoring and oversight), and work (operational duties)" (p. 207). The executive director indicated the dominant theme of most board meetings was informative and not decision making. She acknowledged that her perception of the governance function of the board of directors might be entirely different from that of the board members. This contrasts with what executive directors have identified as critical to board member effectiveness: fund development, 
financial oversight, public relations, commitment and engagement, policy development, and monitoring the performance of the executive director (Brown \& Guo, 2010).

Credibility is critical to the viability of an embryonic nonprofit organization reliant upon fundraising and the goodwill of the community. TSI Rehabilitation relies on fee-for-service billing for substantive financial support. However, this revenue is insufficient to provide for growth and program enhancement. The board of TSI Rehabilitation sees financial management and oversight as one of its primary governance functions, evidenced by the decision to pursue an independent financial audit despite its substantial cost. Board members debated as to whether an audit was more important to the organization than the need to purchase feed for the horses. An independent review was eventually deemed a necessity for two reasons: to establish external credibility and to become eligible for local United Way funding.

Sustainability is a function of the combined effectiveness of organizational governance and professional leadership. Financial viability is the result, but the organization must first articulate its needs. Identifying needs allows the estimate of an accurate monetary cost, which can then drive budgetary, planning, and fundraising efforts. A consensus of need between the governing board and the executive director was not apparent; identified needs included a covered arena to enhance therapy services, regular cash flow, organizational awareness in the local community, and strategic planning. Neither the board of directors nor the executive director had sufficient knowledge of base operational expenditures. A nonprofit organization will likely remain embryonic if it experiences a chronic lack of consistent, reliable funding for mission delivery; sustainability in this embryonic nonprofit organization will continue to be a critical challenge if the leadership cannot articulate the most necessary of costs.

From my perspective, it is not unusual for a nonprofit organization to have an advisory board that provides insight and mentorship to the executive leadership. Prior research suggests boards must consider methods of including stakeholders as sources of information and advisory boards supplement board governance by strengthening relationships with the community (Guo, Metelsky \& Bradshaw, 2014; Saidel, 1998). The advisory boards I have encountered during my nonprofit career were not governing in nature, and the guidance provided to the administration was not binding. The advisory board encountered at TSI Rehabilitation is different from any other than I have experienced, and it appears to have been created solely to provide a voice for the organization's primary benefactor, Susan. The relationship between TSI Rehabilitation, the advisory board, and the executive director is complicated: in addition to the benefactor relationship with TSI Rehabilitation, Susan is the primary employer of the executive director outside of her role with TSI Rehabilitation. The advisory board for TSI Rehabilitation, while unusual in its structure and membership, exists for a particular purpose. The benefactors, who also constitute the advisory board, are aware of a potential conflict of interest, whether real or perceived, due to their multiple connections to the organization. In fact, Susan stated that it would not be proper for her to serve on the governing board of directors; she did not want to be seen as expecting to have influence due to her and her husband's generosity. The organization may consider expanding the advisory board to include client stakeholder representation to provide a forum for input on services delivered and to offer a voice in organizational governance (LeRoux, 2009). 
The reliance of TSI Rehabilitation on a single donor for the delivery of day-to-day operations raises questions about sustainability and survivability. The consensus among the board was that risk does exist due to their lack of knowledge of any legal agreement between TSI Rehabilitation and the benefactors, potential financial hardships to the benefactors that may alter the current arrangement, or a disagreement between the involved parties. This reliance on a single patron presented a concept I had not previously considered: did this reliance upon a single donor restrict the growth and development of the organization? The board president did not agree this relationship limited the organization in any way; however; he acknowledged the organization is constrained by its lack of additional financial resources. The executive director indicated restrictions existed. On multiple occasions, the executive director relied upon the single benefactor to meet short-term financial needs. I posed the same question to the benefactor: did she believe her generosity was creating a dependency on the leadership of TSI Rehabilitation on her, thereby restricting its development and growth? She replied she had not thought of the financial support relationship in that context, stating that she was not certain if her generosity was or was not enabling, but she was certain the organization was not yet financially stable, and its longterm sustainability was not assured. In the context of TSI Rehabilitation, the relationship between the executive director, the advisory board and the governing board of directors is beneficial to the success the organization has experienced.

A dominant theory of organizational management is resource dependency theory, which states that a board of director's primary function is to connect the organization to the sources essential to its survival and its success by providing board capital, for example, financial resources, potential benefactors, advice, council, and so on (Brown, 2005). This theory also acknowledges the board of director's ability to maximize external connections through the leveraging of personal and professional relationships that, in turn, enhance the organization's reputation as well as expand the donor base (Kreutzer, 2009; MillerMillesen, 2003; Mwenja \& Lewis, 2009). TSI Rehabilitation has demonstrated recent success in leveraging personal and professional relationships. On March 16, 2013, a benefit featuring Ryan Mallett, University of Arkansas alumnus and quarterback for the New England Patriots of the National Football League (NFL), was held at the local high school football field. Mallett is related to a recipient of services of TSI Rehabilitation, and a member of the board of directors was able to facilitate his appearance. This local opportunity to meet an NFL quarterback raised $\$ 2,900$ for the organization in a single afternoon (personal communication, March 21, 2013). Resource dependency theory requires the board to link the organization with its environment to maximize the potential resources available because no organization controls the resources need to survive (Miller-Millesen, 2003). The board of TSI Rehablitation effectively deployed resource dependency theory governance without knowing it was doing so.

Strategic planning is virtually nonexistent within the confines of TSI Rehabilitation. The findings clearly indicate that not only do the TSI Rehabilitation board of directors and executive director not engage in any formalized strategic planning but that the organization also continues to operate without any evidence of a business plan. High-performing nonprofit boards have self-identified their responsibility for strategic planning as implementing a strategic planning process and creating mechanisms to address issues arising outside of the formal strategic planning process (Jansen et al., 2006). Board members 
consistently expressed the need for organizational strategic planning for future sustainability and growth but admitted that day-to-day operational survivability was their priority. The need to fundraise in the short-term outweighed the desire to do long-term planning. The governing board, in its current membership paradigm, does not have the experience in nonprofit governance to make the critical connection between strategic planning and long-term sustainability.

\section{Conclusion}

The governing board of TSI Rehabilitation remains embryonic and developmental six years after its inception. The dominant self-perception of the board of directors is that their value as a governing entity is in their willingness to work hands-on in whatever volunteer roles are necessary to sustain the organization. Organizational governance is secondary to this self-characterization as a working board. This lack of focus on formal governance has resulted in a governing structure with minimal development, even as the organization itself continues to enjoy success. TSI Rehabilitation's embryonic state is reflected by a minimum attendance requirement of board members, a very low threshold for establishing a quorum, a lack of rotation in officers of the board, and minimal vetting of potential new members of the board of directors. The orientation and training offered and provided to new board members is non-existent. Little evidence exists of informal or formal strategic planning efforts on the parts of either the executive director or the board of directors. The case study of a single nonprofit entity suggests some recommendations for the practice of nonprofit governance in general as well as future research in the domain of nonprofit organizations that are either embryonic or have limited means available for the professional development of the board.

The primary limitation of this study is that the outcomes of a gap analysis of a single organization through a case study are not transferable to the nonprofit community as a whole. While the process may be replicated in conducting the gap analysis, the findings are not generalizable. Second, the organization selected for this study was a sample of convenience. This sample set was further restricted to organizations with an established operational history of at least two years, and to organizations that are current members of the local United Way. However, the convenience sample does enhance the study through my knowledge of the local community, available resources, comparable services, the local United Way, and in general, the broader nonprofit community. Results of the study are dependent upon the responses of members of the board of directors, the executive director (CEO) and additional relevant individuals, with the assumption that all respondents provided information honestly to me.

My research examined the gap between the expectations of board performance of the nonprofit organization's senior leadership and board members' self-perception of their role in the governance of the organization as well as any effect that gap may have on organizational effectiveness. The findings reveal the potential challenges of the board of directors of an embryonic nonprofit organization but also indicate a need for continued research on the governance of smaller organizations. The normative literature available to the nonprofit community leans towards a prescriptive approach to governance that offers either a checklist of best practices or a formulaic approach to governance, which should result in effective governance but only if properly applied. The academic literature has a disproportionate focus on large and well-financed nonprofit institutions. The research literature 
proposes theoretical constructs such as agency theory, contingency theory, LMX theory, and so on, and assessments and strategic training paradigms which may not be accessible or deployable by the small or embryonic nonprofit corporation. This inability to deploy involved strategic planning mechanisms is confirmed by my exploration of TSI Rehabilitation as well as my anecdotal experience over a twentyyear period as a practitioner in the nonprofit community.

TSI Rehabilitation's leadership and board requested that I provide feedback and recommendations to the organization upon completion of this study. It is an organization with the desire to evolve in operational structure as well as governance effectiveness. The general solution I have experienced and, on occasion, provided is for an organization to identify a need for training for the board of directors, which results in a litany of best practice recommendations to the board membership. I now find that approach to be wholly ineffective.

\section{Recommendations for Future Research}

The exploration of the governance of an embryonic nonprofit with limited governance experience and resources identifies significant areas of future research, including (a) Are there governance traits in embryonic nonprofit organizations not currently identified in academic research? (b) Do governance development and orientation opportunities not yet discovered exist for organizations with minimal governance experience and limited fiscal resources? and (c) identifying cost-effective and viable methodologies for gap analysis in embryonic nonprofit entities. The recommendation is for the practice of gap analysis as an effective means of evaluating the needs of a governing board of directors of a nonprofit entity. The consultant must identify the current knowledge base and governance paradigm of the board combined with the leadership style of executive management. The existing governance theory must be recognized. The information may be gathered in any number of methods based upon the assessment of the current framework (e.g., personal interviews, document reviews, surveys, etc.). Only after the current paradigm and the desired governance outcomes are identified may the consultant propose a course of action to enhance the overall governance effectiveness of any entity. The primary caveat to this approach is the development of a methodology that not only provides efficacy but is feasible in time and financial cost to an organization with limited availability of both.

\section{References}

Abben, D. (2011). Perceptions of the effectiveness of not-for-profit board development opportunities. Theses and Dissertations Paper 78. Retrieved from http://via.library.depaul.edu/etd/78

Beck, D. (2014). Learning to be, learning about: A socio-cultural learning approach to board practice. In C. Cornforth \& W. Brown (Eds.), Nonprofit governance: Innovative perspectives and approaches (103-121). New York, NY: Routledge.

Bloomberg, L., \& Volpe, M. (2008). Completing your qualitative dissertation: A roadmap from beginning to end. Thousand Oaks, CA: Sage Publications Inc. 
Brown, W. (2005). Exploring the association between board and organizational performance. Nonprofit Management \& Leadership, 15(3), 317-339. doi:10.1002/nml.71

Brown, W. (2007). Board development practices and competent board members: Implications for performance. Nonprofit Management \& Leadership, 17(3), 301-317. doi:10.1002/nml.151

Brown, W., \& Guo, C. (2010). Exploring the key roles for nonprofit boards. Nonprofit and Voluntary Sector Quarterly, 39,536-546. doi: 10.1177/089976400933458

Brown, W., Hillman, A., \& Okun, M. (2011). Factors that influence monitoring and resource provision among nonprofit board members. Nonprofit and Voluntary Sector Quarterly, 41, 145-156. doi: $10.177 / 0899764011402510$

Brudney, J., \& Murray, V. (1998). Do intentional efforts to improve boards really work? Nonprofit Management \& Leadership, 8(4), 333-348. doi:10.1002/nml.8403

Callen, J., Klein, A., \& Tinkelman, D. (2003). Board composition, committees, and organizational efficiency: The case for nonprofits. Nonprofit and Voluntary Sector Quarterly, 32, 493-520. doi:10.1177/0899764003257462

Carver, J. (2006). Boards that make a difference: A new design for leadership in nonprofit and public organizations ( $3^{\text {rd }}$ ed.). San Francisco, CA: Jossey-Bass.

Creswell, J. (2007). Qualitative inquiry \& research design. Thousand Oaks, CA: Sage Publications, Inc.

Doherty, A., \& Hoye, R. (2011). Role ambiguity and volunteer board member performance in nonprofit sport organizations. Nonprofit Management \& Leadership, 22(1), 107-128. doi: $10.1002 / \mathrm{nml} .20043$

Flyvbjerg, B. (2006). Five misunderstandings about case-study research. Qualitative Inquiry, 12(2), 219245. doi: $10.1177 / 1077800405284363$

Freiwirth, J. (2014). Community-Engagement Governance: Engaging stakeholders for community impact. In C. Cornforth \& W. Brown (Eds.), Nonprofit governance: Innovative perspectives and approaches (183-209). New York, NY: Routledge.

Glaser, B., \& Strauss, A. (1967). The discovery of grounded theory. Chicago: Adeline.

Green, J., \& Griesinger, D. (1996). Board performance and organizational effectiveness in nonprofit social service organizations. Nonprofit Management \& Leadership, 6, 381-402. doi: $10.1002 / \mathrm{nml} .4130060407$

Guo, C., Metelsky, B., \& Bradshaw, P. (2014). Nonprofit governance research from democratic and critical perspectives. In C. Cornforth \& W. Brown (Eds.), Nonprofit governance: Innovative perspectives and approaches (47-69). New York, NY: Routledge.

Herman, R., \& Renz, D. (2000). Board practices of especially effective and less effective local nonprofit organizations. American Review of Public Administration, 30, 146-160. doi: 10.1177/02750740022064605 
Herman, R., \& Renz, D. (2008). Advancing nonprofit organizational effectiveness research and theory. Nonprofit Management \& Leadership, 18(4), 399-415. doi:10.1002/nml.195

Holland, T. (2002). Board accountability: Lessons from the field. Nonprofit Management \& Leadership, 12(4), 409-428. doi:10.1002/nml.12406

Holland, T., \& Jackson, D. (1998). Strengthening board performance: Findings and lessons from demonstration projects. Nonprofit Management \& Leadership, 9(2), 121-134. doi: 10.1002/nml.9201

Inglis, S., \& Cleave, S. (2006). A scale to assess board member motivations in nonprofit organizations. Nonprofit Management \& Leadership, 17(1), 83-101. Retrieved from http://dx.doi.org/10 $.1002 / \mathrm{nml} .132$

Jansen, P., Kilpatrick, A., \& Cvsa, V. (2006). Creating a dynamic board. Journal of Microfinance/ESR Review, 8(1), 24-31. Retrieved from http://dx.doi.org/10.1109/EMR.2009.5384045

Kendall, K. (2009). The importance of good governance to the ASQ board. The Journal for Quality and Participation, 32(3), 19-20. Retrieved from http://web.ebscohost.com/ehost/pdfviewer/ pdfviewer?vid=3\&sid=7a6224e1-1005-4cbf-9ceb-f947f3f739b5\%40sessionmgr12\&hid=28

Kreutzer, K. (2009). Nonprofit governance during organizational transition in voluntary associations. Nonprofit Management \& Leadership, 20(1), 117-133. doi: 10.1002/nml.244

LeRoux, K. (2009). Paternalistic or participatory governance? Examining opportunities for client Participation in nonprofit social service organizations. Public Administration Review, 69(3), 504517.

Liu, H. (2010). The research on the roles and responsibilities of boards in nonprofit organizations. Nankai Business Review, 1(1), 100-117. doi: 10.1108/20408741011032881

Maykut, P., \& Morehouse, R. (1994). Beginning qualitative research: A philosophic and practical guide. Washington, DC: The Falmer Press.

Maxwell, J. (1998). Designing a qualitative study. In L. Bickman \& D. Rog (Eds.), Handbook of applied social research methods (pp. 69-100). Thousand Oaks: CA: Sage Publications Inc.

Merriam, S. (2009). Qualitative research: A guide to design and implementation. San Francisco, CA: Jossey-Bass.

Miller-Millesen, J. (2003). Understanding the behavior of nonprofit boards of directors: A theory-based approach. Nonprofit and Voluntary Sector Quarterly, 32, 521-547. doi: $10.1777 / 0899764003257463$

Mwenja, D., \& Lewis, A. (2009). Exploring the impact of the board of directors on the performance of not-for-profit. Business Strategy Series, 10(6), 359-365. doi: 10.1108/17515630911005646

O'Regan, K., \& Oster, S. (2005). Does the structure and composition of the board matter? The case of nonprofit organizations. Journal of Law Economics \& Organizations, 21(1), 205-227. doi: 10.1093/jleo/ewi009 
Ostrower, F., \& Stone, M. (2009). Moving governance research forward: A contingency-based framework and data application. Nonprofit and Voluntary Sector Quarterly, 39(5), 901-924. doi: 10.1177/0899764009338962

Renz, D., \& Andersson, F. (2014). Nonprofit governance: A review of the field. In C. Cornforth \& W. Brown (Eds.), Nonprofit governance: Innovative perspectives and approaches (17-46). New York: Routledge.

Rossman, G., \& Rallis, F. (2003). Learning in the field ( $2^{\text {nd }}$ ed). Thousand Oaks, CA: Sage Publications, Inc.

Saidel, J. (1008). Expanding the governance construct: Functions and contributions of nonprofit advisory groups. Nonprofit and Voluntary Sector Quarterly, 27(4), 421-436. doi: 10.1177/0899764098274003

Silverman, D. (2000). Doing qualitative research: A practical handbook. Thousand Oaks, CA: SAGE Publications.

Stone, M., \& Ostrower, F. (2007). Acting in the public interest? Another look at research on nonprofit governance. Nonprofit and Voluntary Sector Quarterly, 36, 416-438. doi: 10.1177/08997604006296049

Tellis, W. (1997).Introduction to case study. The Qualitative Report, 3(2). Retrieved from http://www .nova.edu/ssss/QR/QR3-2/tellis1.html

Wolf, T. (1999). Managing a nonprofit organization in the twenty-first century. New York, NY: Fireside.

\section{About the Author}

Dr. Jeff Aulgur, Ed.D. (jaulgur@atu.edu) is the Department Head of the Department of Professional Studies at Arkansas Tech University, and he has served in this capacity since May 2011. Before his academic appointment, Dr. Aulgur served as the Director of the Professional Development Institute at Arkansas Tech University. He earned his Doctor of Education in Workforce Development from the University of Arkansas in 2013. His research focuses on the governance of nonprofit organizations and the application of governance theory. Dr. Aulgur instructional interests include nonprofit organizations, the application of adult learning theory, and the application of leadership theory. 